\title{
Henry Morgentaler: model for the UK?
}

\section{Vincent Argent}

Consultant Obstetrician and Gynaecologist, East Sussex, UK

Correspondence to Dr Vincent Argent; vincent_argent@hotmail.com

Received 16 July 2013 Revised 20 July 2013 Accepted 21 July 2013
To cite: Argent V. J Fam Plann Reprod Health Care 2013;39:247-249.

\section{BACKGROUND}

The life of Henry Morgentaler (19 March 1923 to 29 May 2013), ${ }^{1}$ the Canadian doctor and abortion rights activist, has important lessons for the future of abortion law in the UK.

Canada is the only country in the developed or developing world where abortion is not a criminal offence (apart from the Australian states of Victoria and Australian Capital Territory).

Morgentaler was, and still is, a household name in Canada and, of all doctors in the world, is the one most closely linked with women's rights and selfdetermination to choose to end their pregnancy.

In the landmark case of $R v$ Morgentaler $1988,{ }^{2}$ the Supreme Court of Canada ruling declared that the law prohibiting abortion was unconstitutional in the context of the Canadian 'Charter of Rights and Freedoms'. Abortion was decriminalised and, to this day, is no longer a criminal offence in Canada. The law neither condones nor condemns induced abortion. It remains for each province to decide on the availability and funding of induced abortion under the Canada Health Act.

Morgentaler's steadfast activism won many supporters but he was also vilified by his opponents; in 2008 he received Canada's highest civilian order, the Order of Canada. Morgentaler commented that he was proud to have realised his dream of a better and more human society. The citation was "For his commitment to increased health care options for women, his determined efforts to influence Canadian public policy and his leadership in humanist and civil liberties organisations".

\section{MORGENTALER'S EARLY LIFE}

Henryk Morgentaler was born in Łódź, Poland in 1923 to Josef and Golda Morgentaler. His father was active in the large Jewish community and the General Jewish Labour Bund. Under the German occupation, Morgentaler's father was killed by the Gestapo while Henryk lived with his mother and younger brother in the Łódź ghetto. Eventually they were taken to Auschwitz where his mother died while the boys were sent to work in Dachau. On liberation, Henryk weighed a mere $32 \mathrm{~kg}$ and was sent to a displaced persons hospital. He went on to Brussels to study medicine and met up with his childhood sweetheart and future wife, Chava Rosenfarb. They married in 1949 and sailed to Canada on the SS Samaria.

Morgentaler continued his medical studies, graduating from the Université de Montréal in 1953. He practised as a general practitioner in the east end of Montréal and was one of the first Canadian doctors to provide contraceptive advice to single patients as well as married couples.

\section{ABOLITION OF THE TAC PROCESS}

While David Steel was introducing his Private Members Bill to liberalise UK abortion law, many in Canada were also concerned that abortion had been completely banned since 1869 but that illegal abortions were common, with several hundred deaths per year. In a familiar comment, Morton Shulman, the Chief Coroner of Ontario, said that pregnant daughters of the rich were sent to reliable physicians who did abortions for cash, while he had the unpleasant experience of seeing the bodies of young women who had died as a result of amateur abortions. In 1967, Justice Minister Pierre Trudeau, later Prime Minister, introduced the Criminal Law Amendment Act, 1968-69, which was passed in May 1969 and which provided for abortions where the health of the woman was in danger as determined by a three-doctor hospital Therapeutic Abortion Committee (TAC). The same Bill also legalised homosexual 
acts and contraception. Trudeau's most famous quotation was that "The State has no business in the bedrooms of the nation".

But the practice of requiring the approval of the three-doctor TAC proved far more troublesome than the UK requirement for two doctors' signatures and the opinion formed in good faith. There were huge variations between individual hospitals and provinces, and many hospitals did not have TACs as there was no legal requirement to do so.

Morgentaler campaigned for the abolition of the TAC process. He was a humanist and staunch defender of the woman's right to choose. He opened several clinics where he and his associates carried out abortions on request without going through a TAC. While having many supporters in the Metropolitan areas, it is interesting that he received more support from largely Roman Catholic Quebec than the more conservative Anglo-Saxon Maritime and Prairie provinces. For Morgentaler, there followed many years of protests, legal battles and prosecutions. Between 1973 and 1975, he was prosecuted for defying the law in Quebec but on each occasion he evoked the legal doctrine of necessity and each time was acquitted by the jury. The Quebec Court of Appeal overturned the jury acquittals and convicted Morgentaler and he was sentenced to 18 months in prison from March 1975. Shortly after, under the new Liberal Prime Minister, Pierre Trudeau, Parliament changed the law so that Appeals Courts could no longer overturn jury verdicts but only order a new trial. This landmark ruling is known as the Morgentaler Amendment to the Criminal Code of Canada.

Morgentaler spent 10 months in prison. He spent time in solitary confinement, lost weight from his meagre frame and suffered a heart attack. On his release, he became even more of a public hero to women and he continued his abortion practice and opened a new clinic in Toronto. He was supported by the Canadian Association for the Repeal of the Abortion Law (CARAL), and by 1983 a Gallup poll showed that $72 \%$ of Canadians believed that the decision to have an abortion should be solely that of the pregnant woman and her doctor.

Eventually, following further conviction in Ontario, Morgentaler again appealed to the Supreme Court of Canada, stating that the law was unconstitutional on the grounds that it denied women the right to life, liberty and security of the person. On 28 January 1988, the Supreme Court of Canada gave its landmark decision in $R v$ Morgentaler. It was a criminal law case but the Supreme Court examined women's rights in the context of the Charter of Rights and Freedoms. In Morgentaler, the Supreme Court ruled that the federal government's criminal legislation was unconstitutional and that women had the same control of their bodies as did men. In a case that may have persuasive analogy for changes to UK law, in
Canadian law Morgentaler ranks with the Persons case regarding the definition of Canadian women's constitutional rights as the UK Judicial Committee of the Privy Council, then Canada's highest court of appeal ruled that women are persons equal to men.

The Supreme Court issued a 5-2 decision in Morgentaler. The leading reply of Chief Justice Dickson and Judge Lamer was that Section 251 (the abortion provision) of the Criminal Code of Canada infringed and denied the rights and freedoms of the Canadian Charter of Rights and Freedoms. They stated that state interference with bodily integrity and serious state-imposed psychological stress, at least in the criminal law context, constitutes a breach of security of the person. Section 251 clearly interferes with a woman's physical and bodily integrity. Forcing a woman, by threat of criminal sanction, to carry a fetus to term unless she meets certain criteria unrelated to her own priorities and aspirations is a profound interference with a woman's body and thus an infringement of security of the person. A second breach of the right to security of the person occurs independently as a result of the delay in obtaining therapeutic abortions caused by the mandatory procedures of s.251 which results in a higher probability of complications and greater risk. The harm to the psychological integrity of women seeking abortions was also clearly established. Any infringement of the right to life, liberty and security of the person must comport with the principles of fundamental justice.

The overall result was that Canadian law regulating abortion was struck down and this is still the case.

\section{MORGENTALER'S LATER LIFE}

Curiously, this thin and bowed, bearded man, lacking his own teeth since earlier years, was attracted and attractive to many women. He was a zealot, polyglot and polymath. After his stay in prison, he broke up with his childhood sweetheart. He remarried twice and also, by his own admission, had many mistresses. His biographer, Catherine Dunphy, wrote in Morgentaler: A Difficult Hero that he was a man who loved women and couldn't be monogamous. The loss of his mother at Auschwitz haunted him and he said that throughout his life had had been looking for the mother's love that he missed. He felt that this explained his relationships with women as, deep down, he was afraid that they would leave him or stop loving him. His behaviour was "a psychological strategy to make sure there would always be a woman who loves me". He died with his beloved third wife, Arlene Leibovitz, at his side.

\section{SIGNIFICANCE OF MORGENTALER FOR THE UK}

What is the importance of Morgentaler for the UK? Should England, Wales and Scotland follow Canada and decriminalise induced abortion? The Abortion Act 1967 (as amended by the Human Fertilisation and 
Embryology Act 1990) was passed 46 years ago and there have been many attempts to make the law more liberal or more restrictive. The politicians merely leave such attempts to private members allowing votes on conscience. The lack of action after the 2007 House of Commons Science Technology Select Committee Review of Scientific Developments Relating to Abortion shows how Parliament has little wish to get involved in tackling the law.

The law is a blunt instrument and can never reconcile the pro-choice lobbyists and the pro-life lobbyists who are often vehement in their wish for changes that are anathema to their opposition. The recent Parliamentary Inquiry into Abortion on the Grounds of Disability, July 2013, recommends that Parliament review the law surrounding Section 1(1)(d) concerning fetal disability, but again politicians will find it impossible to produce a law that satisfies widely divergent views and they are unlikely to take any action. The recent ham-fisted Care Quality Commission investigation into the requirement for two doctors' signatures on the HSA1 form showed how UK abortion law languishes in an era of medical paternalism. The general pragmatic public view rarely gets a voice. Most people agree that women should be able to choose early abortion without needing sanction by doctors, but have some concerns about later abortions around the stage of viability and abortion for other reasons such as minor fetal abnormality and sex selection. The Abortion Act 1967 is fit for purpose in the sense that criminal activity has all but disappeared and there are few prosecutions of women who self-administer abortifacients. Would it not be better if there was no law and that women, supported by their heath care advisers and providers, could choose abortion based on their own free will and their own ethical and moral judgements of what is best while health care services provide what is deemed reasonable by the majority of society? Those who find induced abortion abhorrent and immoral would be free to make their own decisions accordingly.

$R v$ Morgentaler was a Canadian Supreme Court decision. The problems of abortion practice and the views of the majority of the people were similar to the UK. The jurisdictions are similar and the legal decision may be persuasive, even if it does not set a precedent, in the UK Supreme Court. Should the UK follow the modern progressive step taken by Canada and declare that the Abortion Act 1967 is a breach of the Human Rights Act 1998 provisions on the fundamental rights and freedoms of the individual and thereby decriminalise abortion?

Competing interests None.

Provenance and peer review Not commissioned; externally peer reviewed.

\section{REFERENCES}

1 Obituary - Henry Morgentaler. http://www.thelancet.com/ journals/lancet/article/PIIS0140-6736\%2813\%2961517-2/ fulltext?rss=yes [accessed 18 July 2013].

$2 R v$ Morgentaler. http://www.law.ualberta.ca/centres/ccs/rulings/ rvmorgentaler.php [accessed 18 July 2013]. 